\title{
$65^{\text {th }}$ birthday of Prof. Jozef Halgoš
}

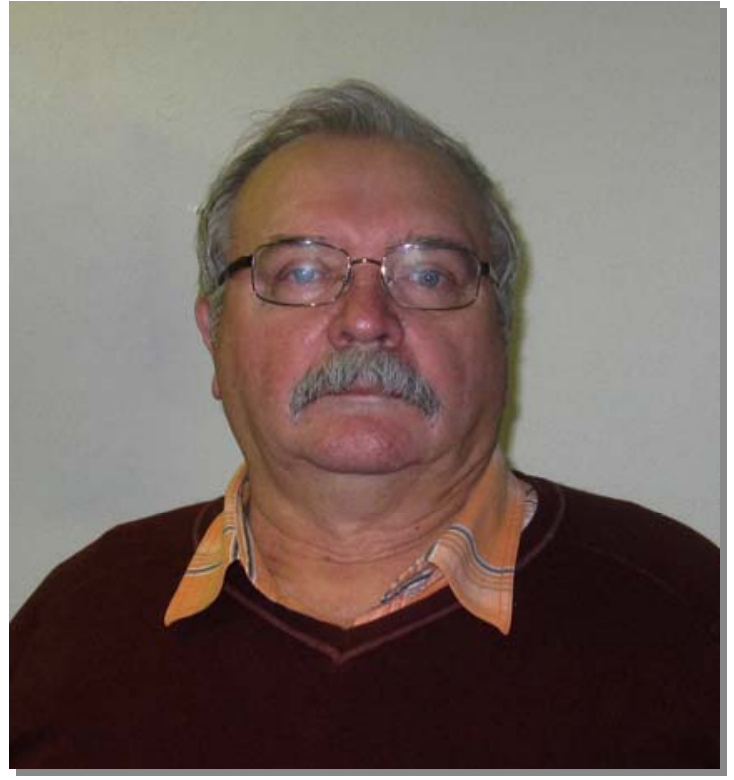

A distinguished Slovak scientist and university teacher, biologist, parasitologist and ecologist Prof. RNDr. Jozef Halgoš, DSc. was born on November, 23, 1946 in a village of Soblahov near Trenčín. After graduation from the Commenius University, Faculty of Natural Sciences (1965 - 1970) with a degree in biology and chemistry and specialising in zoology, he started work at the Department of Systematic and Ecological Zoology at the Faculty of Natural Sciences, CU as a research assistant. In 1974 he was transferred to Zoological Institute (now Institute of Ecology) of the Faculty of Natural Sciences of the CU, having served first as the head of the Department of Parasitology, deputy director and in $1994-1996$ he was appointed a director of the Institute. Prof. Halgoš was instrumental in transforming the Institute into the Department of Ecology in 1998 and he held the position of the head of the Department until September 2011.

Prof. Halgoš received his $\mathrm{PhD}$. degree from parasitology from the Institute of Parasitology CSAS in Prague in 1980. He defended his doctoral thesis in 1989 at the Institute of Zoology, AS in Leningrad, obtaining his degree the Doctor of Sciences in 1990. He habilitated in 2000 and in 2003 he was appointed a Professor of Ecology.

Since his appointment at the Faculty of Natural Sciences of CU, Prof. Halgoš has supervised lectures and seminars not only in zoology of invertebrates, parasitology, but also in Medical Geography and he also led a course in Tropical Medicine at the Institute for further education of Physicians and Pharmaceuts. Later he lectured on Parasitology for ecologists, Evolutionary Parasitology, Medical Entomology, Methods and Techniques in Parasitology, Ecology of Diptera and other subjects. He supervised numerous undergraduate students, PhD. students both from home and abroad, four assistant professors and three professors.

His pedagogical and scientific activities extended far beyond the borders of the former Czechoslovakia and the Slovak Republic. He was a member of the Advisory Board for the research of human onchocercosis in Africa and for the research of fauna in Greece. At present, he organises an international cooperation between the Department of Eco-1ogy of CU and the Department of Ecology of the University of Silesia in Katowice and the Zoological Institute of Russian Academy of Sciences in Saint Petersburg. He has joined several scientific expeditions, e.g. to Mongolia, Vietnam, Russia, Africa, Middle East, Morocco and Greece.

His wide ranging scientific interests have included investigating various problems in the field of biology and ecology of blood-sucking Diptera (flies and mosquitoes) and other important parasitic species. As a principal investigator and investigator he has participated in 21 expertise studies. $\mathrm{He}$ published more than 120 scientific contributions at home and abroad, numerous papers in popular and scientificpopular journals, authored several monographs, and five university textbooks.

Prof. Halgoš sits on several boards, where he has devoted considerable time, energy and wisdom. He has actively acted as a member of various scientific societies - parasitological, zoological and entomological. His many important contributions to the international scientific community have been recognized by, amongst others, the medal of Prof. Hovorka, the medal of Stanislava Prowázka, the medal of Karol Brančík, the silver medal of the Faculty of Natural Sciences of the Commenius University, the golden medal of the Commenius University and the golden medal of the University of Silesia in Katowice. He is also a holder of the State Award of the Mongolian People's Republic.

His prolific scientific and social life is characterised by abundant inventiveness and limitless creativity. A love for horses has turned into a lifelong hobby, now he acts as a judge at various equine competitions. And last, but not least, remarkable is his flair for playing with thoughts and words, resulting in a work of poetry that attracts even the most discerning reader.

It is with great pleasure we would like to wish a very Happy Birthday to a great mentor and a wonderful person. May you be blessed with love, enthusiasm, and prosperity always.

AD MULTOS ANNOS

František Ondriska 